\title{
Seasonal Histology of the Testes of Nile Tilapia (Oreochromis niloticus)
}

\author{
El-Sakhawy, M.A; El-Saba, A.A; Abd Rabou, M.I; El- \\ Shammaa, M.A; and Hussein, S.H
}

Department of Cytology and Histology, Faculty of Veterinary Medicine Cairo University.

With 12 figures

Received August, accepted for publication September

2011

\section{Abstract}

In the present research, the histology of the testes of Nile tilapia were done on 56 males sexually mature Nile tilapia fish collected monthly from the River Nile at Giza over the period from September 2009 to August 2010. The testis of the Nile tilapia during the spring, summer and autumn seasons was surrounded by very thin tunica albuginea. The testicular capsule extended inside the testis to give connective tissue septa. The bulk of the testis was composed of seminiferous tubules. These tubules were surrounded by interstitium. The tubules filled with germinal cysts; contained germinal cells at different stages of development and surrounded by cytoplasmic processes of Sertoli cells. The spermatogenic cells were spermatogonia type $A$ and type $B$, primary spermatocytes, secondary sperma- tocytes, spermatids and spermatozoa. The interstitium filled the intertubular spaces and was composed mainly of fine collagenous connective tissue which contained abundant Leydig (interstitial) cells and blood capillaries. The testis during winter appeared evacuated from the spermatozoa with no cystic arrangement of the germinal cells. The testis showed different degrees of vacuolation. The tubular lumen contained residual sperms. The vacuoles appeared in the Sertoli cells. Phagocytic cells were observed in close association of the basement membrane of Sertoli cells.

\section{Key words}

Oreochromis niloticus, testis

\section{Introduction}

Nile tilapia belongs to genus Oreochromis. This species is natu- 
rally distributed in the Nile River as well as most parts of African Rivers and lakes (Trewavas, 1982). Oreochromis niloticus is gonochoristic, which each individual possessing a single sexual phenotype. Nile tilapia is characterized by extended spawning seasons, reaching maturity at small size and fast growth rate. It has been termed the aquatic chicken for its extraordinary production capabilities (Peterson et al., 2004).

The gonads are of greater functional significance than their name implies and they were investigated by several workers in different fish species Dougbag, et al., (1988) in Oreochromis niloticus; Mousa (1998) in Oreochromis niloticus; Gaber (2000) in Bagrus docmac and Bagrus bayad and El-Zoghby et al., (2009) in Clarias lazera.

As far as we are aware, there are few references dealing with the seasonal changes in the histology of the testes of Nile tilapia (Oreochromis niloticus) (El-Gohary, 2001). The principle objectives of the present investigation was to study the seasonal activity of the testes to provide a clear information which could be useful for both scientists and who are concerning with aquaculture development.

\section{Materials and Methods}

Specimens of Nile tilapia (Oreochromis niloticus) were collected monthly at the same time of the day from the River Nile at Giza. A total of 56 males were collected over the period from September 2009 to August 2010. Fish were transported alive to the central lab. of Cytology and Histology department, Faculty of Veterinary Medicine Cairo University. Fish were physically examined to ensure that they were free from any pathological changes. Each Nile tilapia was weighted (700$850 \mathrm{gms}$ ) to ensure that all fish sexually mature as mentioned by Popma and Masser (1999). The testes were carefully separated of 1 cubic $\mathrm{cm}$. Sections were taken quickly from cranial, middle and caudal parts and were fixed in neutral buffered formalin for about $24 \mathrm{hs}$. also Bouin's fluid and Zenker's formol were used. After proper time of fixation for each fixative the samples were dehydrated, embedded in paraplast and following that $5-6 \mu \mathrm{m}$. sections were cut.

The following staining procedures were adopted for examination of testis:

1. Harris haematoxylin and eosin (H\&E) for general histological examination.

2. Crossmon's trichrome stain for identification of collagen fibers and 
smooth muscle fibers (Crossmon, 1937).

3. Weighert's elastic stain for demonstration of elastic fibers.

4. Gomori's reticuline method for demonstration of reticular fibers.

The aforementioned fixatives and staining methods were used as outlined by Drury and Wallington (1980).

\section{Results}

\section{The histological appearance of the testis during spring, sum- mer and autumn}

The testis of the Nile tilapia (Oreochromis niloticus) was surrounded by very thin tunica albuginea which was consisted of dense collagenous connective tissue with few fine elastic fibers, they extended inside the testis to give connective tissue septa. This tunica albuginea was covered externally by mesothelium (Fig. 1). The bulk of the testis was composed of seminiferous tubules. These seminiferous tubules were oriented at right angles to the long axis of the testis and they were ended blindly at its periphery (Fig. 2). The testicular tubules were surrounded by fusiform shaped myoid cells (Fig. 3).

The seminiferous tubules were filled with germinal cysts. The germinal cysts contained germinal cells at different stages of development. All stages were not simultaneously present along one given tubule, as a cyst containing spermatogonia could be adherent to one cyst containing spermatids (Fig. 3).

The testicular tubules were surrounded by reticular fibers (Fig.4). The testicular tubules were larger and were distended with different spermatogenic stages with the appearance of huge number of spermatozoa in their lumen. All stages of spermatogenesis were predominant (Fig. 5).

The interstitium filled the intertubular spaces and was composed mainly of fine collagenous connective tissue which contained abundant interstitial Leydig cells and blood capillaries. The interstitial Leydig cells were polygonal in shape, with illdefinite cell boundaries. They had centrally located spherical nuclei (Figs. 3, 6).

The testicular tubules contained two types of cells; one of them was spermatogonia which give rise to different generation of spermatogenic cells in germinal cyst, while the other was Sertoli cells.

\section{I- Sertoli cells}

They had flattened and elongated dense nuclei. They surrounded the germinal cysts as their cytoplasmic processes shared in formation of 
the wall of germinal cysts (Figs. 3, 7). Sertoli cells were present in contact with the basal lamina, also they were found at the periphery of the testicular tubules (Fig. 8). Also, they surrounded the spermatogonia (Figs. 9).

\section{II- The spermatogenic cells}

The spermatogenic (germ) cells were spermatogonia, primary spermatocytes, secondary spermatocytes, spermatids and spermatozoa. They showed asynchronous development where all spermatogenic stages could be seen within the same tubules.

\section{1- Spermatogonia}

They were the largest spermatogenic cells. There were two types of spermatogonia: the first type was spermatogonia type $A$, which were found solitary under the tunica albugenia or close to the periphery of testicular tubules. They were large rounded cells with large rounded vesicular nuclei. Their cytoplasm was faintly stained (Fig. 10). The second type was type B spermatogonia, which were smaller in size and they had clumps of dense chromatin within their nuclei and were found deeper in the testicular lobules. (Figs. 9,10 ).

\section{2- Primary spermatocytes}

They were found in germinal cysts. They were smaller than spermatogonia. Their nuclei were spherical in shape with deeply stained chromatin (Figs. 6, 7). Numerous mitotic figures were observed among them.

\section{3- Secondary spermatocytes}

They were slightly smaller than the primary spermatocytes. They were found in germinal cysts. They characterized by their large nuclei occupying most of the cells that were surrounded with thin rim of cytoplasm. Their nuclei had condensed chromatin. Secondary spermatocytes were difficult to be observed.

\section{4- Spermatids}

They were smaller than the previous germ cells. They were found in cysts and appeared as small cells of indistinct outline with scanty cytoplasm and dense spherical nuclei. Some cysts of spermatids ruptured and the spermatids released into the tubular lumen (Figs. 1, 10).

\section{5- Spermatozoa}

They were the smallest cells of the spermatogenic lineage. They were present in the lumen of the seminiferous tubules without any arrangement, after their releasing from the germinal cysts of the spermatids which exposed to modification to be transformed into spermatozoa. The spermatozoa were characterized by deeply stained rounded heads with very fine protoplasmic tails (Figs. 6 and 8). 


\section{The histological appearance of the testis during winter sea- son:}

The testis appeared evacuated from the spermatozoa with no cystic arrangement of the germinal cells with increase the thickness of the tunica albuginea (Fig. 11). The tubular lumen contained residual sperms from the previous spawning season. The testis showed different degrees of vacuolation. The vacuoles appeared in the Sertoli cells. Phagocytic cells were observed in close association with the basement membrane of Sertoli cells (Fig. 12). The Leydig cells were less in field occupation and smaller in size and some appeared with pyknotic nuclei.

\section{Discussion}

Our investigation found that, the tunica albuginea in the testis of the Nile tilapia (Oreochromis niloticus) had no uniform thickness all over the year but, it reached a maximum thickness during winter and became thin during spring, summer and autumn. The reason might be due to pressure exerted on the tunica albuginea by the distended tubules, as explained by Stoskof (1993).

Our result revealed that the Leydig (interstitial) cells were present in the intertubular spaces with numerous blood capillaries. This result was similar to those of Van Vuren and Soly (1990) in Tilapia rendalli; Mousa (1998) in Oreochromis niloticus; Nakaghi et al., (2003) in Colossoma macropomum and Smita et al., (2005) in Ichthyophis tricolor. Leydig cells were poly gonal in shape, with ill-definite cell boundaries and had centrally located spherical nuclei. They were present throughout the year with seasonal morphological changes in corresponding to reproductive cycle as they decreased in number and had pyknotic nuclei during winter and increased in the following breeding seasons where active spermatogenesis was going on. This finding was agreed with the result of Zaki et al., (1986) in Clarias garipienus; Colombo et al., (1987) in silver eel (Anguilla anguilla); Mollah (1988) in Clarias macrocephalus; Mousa (1998) and El-Gohary (2001) in Oreochromis niloticus.

Unlike the mammals, the testis of the Nile tilapia lacked a permanent spermatogenic cells, but their spermatogenic cells were arranged in form of germinal cysts. This result was in agreement with the results of most of previous authors but differed with Cinquetti and Dramis (2003) who stated that the seminiferous tubules of Padogobius martensi were lined by a simple epithelium of primary spermatogonia and Sertoli cells. 
Our result revealed that, the Sertoli cells were found at the periphery of the seminiferous the testicular tubules as recorded by Leatherland and Sonstegard (1978) who described that Sertoli cells in Cyprinid fish testis were situated at the periphery of the seminiferous lobules, where they were in contact with the basement membrane, also this result obtained by Mousa (1998) in Oreochromis niloticus. While, Yeung et al., (1985) in Monopterus albus and Van Vuren and Soly (1990) in Tilapia rendalli mentioned that Sertoli cells surrounded by a basal lamina, laid between the testicular lobules and the interstitium.

Our finding showed that, the seminiferous tubules contained many different germinal cysts and each cyst had the same spermatogenic stage. The germinal cysts were surrounded with the cytoplasmic processes of the Sertoli cells that shared with very thin collagen fibers in formation of the wall of cysts. This resembled the results of Arenas et al., (1995) in Gambusia affinis and Nakaghi et al. (2003) in Colossoma macropomum. Sertoli cells were also found surrounding the spermatogonia and this was supported by the results of Abd El-Aziz (1992) in Oreochromis niloticus.

In the present study, the spermatozoa increased within the lumen of testicular tubules during spring,

J. Vet. Anat. summer and autumn and the testicular tubules showed different activity where some tubules were filled with spermatozoa and others were spent or empty as they discharged their content during spawning, that was similar to result of Nayyar and Sundararaj (1970) in Heteopneustes fossilis; Latif and Salem (1983) in Lethrinus nebulosus; Resink et al., (1987) in Clarias gariepinus; Gaber (2000) in Bagrus docmac and Bagrus bayad and Guerriero et al., (2005) in Leuciscus cephalus.

In agreement with Abd El-Aziz (1981) in Sparus aurata and ElSaba (2007) in gilthead sea bream (Sparus aurata), the germinal cysts were absent in post spawning and resting testis.

El-Saba (2007) in gilthead sea bream (Sparus aurata) fish mentioned that, the testes in post spawning stage showed some degrees of vacuolation, which were more prominent in the cytoplasm of the Sertoli cells together with degenerated spermatozoa. Our results in the testes of Oreochromis niloticus during winter (non breeding season) support these findings. The presence of vacuoles was considered as result of phagocytosis by the Sertoli cells to the spermatozoa, which had remained in the testes after completion of the spawning season (Billard, 1983 and Dziewulska and Domagala, 2002). 


\section{References}

Abd El-Aziz, M. (1981): Reproduc tive biology of sparus aurata in the Mediterranean sea water of Alexandria. Ph.D. thesis, Oceanography department, Faculty of Science, Alexandria University.

Abd El-Aziz, M. (1992): An ultra structure study on the spermatogenesis of Oreochromis niloticus (Tilapia) fish during winter season. Egypt. J. Histol., 15: 269 - 281.

Arenas, M.I.; Fraile, B.; Paz De Miguel, M. and Paniagua, R. (1995): Cytoskeleton in Sertoli cells of Mosquito fish, Gambusia affinis holbrooki. Anat. Rec., 241: 225 - 234.

Billard, R. (1983): Spermatogene sis in the rainbow trout (Salmo gairdneri). An ultrastructural study. Cell and Tissue Research, 233: 265 284.

Cinquetti, R. and Dramis, L. (2003): Histological, histochemichal, enzyme histochemical and ultrasatructural investigations of the testis of Padogobius martensi between annual breeding seasons. J. Fish Biol., 63: 1402 $-1428$.
Colombo, G.; Grandi, G.; Romeo,

A.; Giovannini, G.; Pelizzola, D.; Catrozzi, L. and Piffanelli, A. (1987): Testis cytological structure, plasma sex steroids, and gonad cytosol free steroid receptors of heterologous gonadotropin (hCG)-stimulated silver eel, Anguilla anguilla L. Gen. Comp. Endocrinol. 65, 167178.

Crossmon, G. (1937): A modifica tion of mallory's connective tissue stain with discussion of principle involved. Ibid., 69: 33-38.

Dougbag, A.; El-Gazzawy, E.; Kassem, A.; El-Shewemi, S.; Abd El-Aziz, M. and Amin, M. (1988): Histological studies on the testis of Tilapia niloticus. I. Basic structures. Alex. J. Vet. Sci., 4: 49 - 58.

Drury, R. A. B. and Wallington, E.

A. (1980): Carleton's histological technique. Fourth Edition Oxford University Press, New York, Toronto.

Dziewulska, K. and Domagala, J. (2002): Histology of Salmonid testes during maturation. Rep. Biol., 3(1): 47-61.

El-Gohary, N.M.A. (2001): The effect of water quality on the reproductive biology of the Nile tilapia, Oreochromis niloticus in Lake Manzalah. 
Ph.D. Thesis. Faculty of Science. Ain Shams University.

El-Saba, A.A. (2007): Histological, histochemical and electron microscopic studies on testis of gilthead sea bream (Sparus aurata). Ph.D.thesis, Histology and Cytology department, Faculty of Veterinary Medicin, Cairo University.

El-Zoghby, I. M. A.; Bakry, H. H.;

Ghallab, A. M. and Emam, M. A. (2009): Histological studies on the gonads of the catfish during different seasons. Lucrari Stiintifice USAMV Lasi, Medicina Veterinara Vol.52 (11): 352 362.

Gaber, S.A.O. (2000): Biological, histological and histochemical studies on the reproductive organs and pituitary gland of Bagrus docmac and Bagrus bayad in the Nile water, with special reference to the Ultrastructure of supporting tissues. Ph.D.Thesis. Faculty of Science, Zagazig Univeristy.

Guerriero, G.; Ferro, R. and Ciar cia, G. (2005): Correlations between plasma levels of sex steroids and spermatogenesis during the sexual cycle of the chub, Leuciscus cephalus L. (Pisces: Cypri- nidae). Zoological Studies, 44: 228 - 233.

Latif, A.F.A. and Salem, S.A. (1983): Sexual cycle of Lethrinus nebulosus (Forsk.) in the Red Sea. II. Microscopic peculiarities of the testis. Egypt. J. Histol., 6: 141 158.

Leatherland, J. F. and Sonste gard, R. A. (1978): Structure of normal testis and testicular tumor in cyprinides from Lake Ontario. Cancer Res. 38: $3164-3173$.

Mollah, M.F.A. (1988): The annual cycle of the testes of freshwater catfish, Clarias macrocephalus. Indian J.Fish., 35: 99- 106.

Mousa, A. M. (1998): Immunocyto chemical and Histological studies on the reproductive endocrine glands of the Nile tilapia, Oreochromis niloticus (Teleostei, cichlidae). J. Egypt. Ger. soc. zool., 27: $109-134$.

Nakaghi, L. S. O.; Mitsuiki, D.;

Santos, H. S. L.; Pacheco, M. R. and Ganeco, L. N. (2003): Morphometry and morphology of nucleus of the Sertoli and interstitial cells of the tambaqui Colossoma macropomum (Cuvier, 1881) (Pisces: Characidae) during the reproductive cycle. Braz. J. Biol., 63. 
Nayyar, S.K. and Sundararaj, B.I.

(1970): Seasonal reproductive activity in the testes and seminal vesicles of the catfish, Heteopneustes fossilis (Bloch). J. Morph., 130: 207 $-225$.

Peterson, M.S.; Brown-Peterson, N.J. and McDonald, J.L. (2004): Reproduction in nonnative environments: establishment of the Nile Tilapia Oreochromis niloticus in coastal Mississippi watersheds. Copeia: 842-849.

Popma,T and Masser,M (1999) :

Tilapia life history and biology.SRAC Publication No.283 Resink, J.W.; Van den Hurk, R.; Voorthuis, P.K.; Terlou, M.; DE Leeuw, R. and Viveen, W.J.A.R. (1987): Quantitative enzymehistochemistry of steroid and glucuronide synthesis in testis and seminal vesicle, and its correlation to plasma gonadotropin level in Clarias gariepinus. Aquuculture, 63: 97 - 114.

Smita, M.; Beyo, R.S.; George,

J.M.; Akbarsha, M.A. and Oommen, O.V. (2005): Seasonal variation in spermatogenic and androgenic activities in a caecilian testis (Ichthyophis tricolor). J. Zool., 267: 45 - 53.

Stoskopf, M.K. (1993): Bacterial diseases of sharks. In: Fish Medicine (ed. by M.K. Stoskopf), pp. 774-775. W. B. Saunders Company, Philadelphia, PA.

Trewavas, E. (1982): Tilapias: taxonomy and speciation. In: Pullin, R. S. V., and LoweMcConnell, R. H. (eds): The Biology and Culture of Tilapias. Pp: 3-13. ICLARM Conf. Proc. 7, ICLARM, Manila, Philippines.

Van Vuren, J.H. and Soly, J.T. (1990): Some ultra-structural observation of Leydig and Sertoli cells of Tilapia rendalli following induced testicular recrudescence. J. of Morph. 206: $57-63$.

Yeung, W.S.B.; Adal, M.N.; Hui,

S.W.B. and Chan, S.T.H. (1985): The ultra-structural and biosynthetic characteristics of steriodogenic cells in the gonad of Monopterus albus during natural sex reversal. Cell Tissue Res. 239: $383-394$.

Zaki, M.I.; Dowidar, M.N. and abdala, A. (1986): Reproductive biology of Clarias gariepinus (Syn, lazera) Burchell (clariidae) in lake Manzalah, Egypt. II. Structure of the testes. Folia Morphologica, 43: $307-313$. 

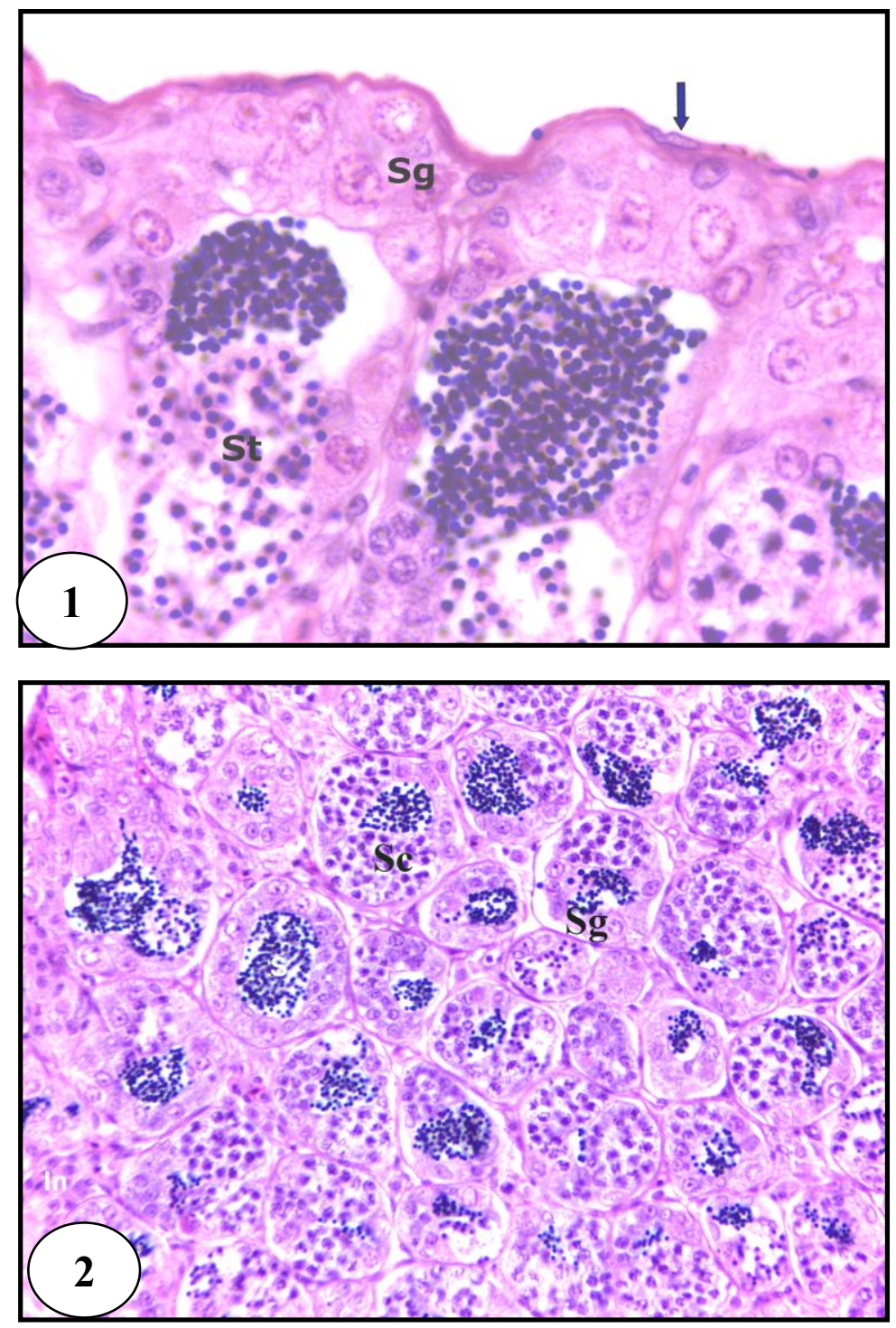

Fig (1) Section of testis of Nile tilapia during summer showing: Very thin tunica albuginea covered externally by mesothelium (arrow), Spermatogonia (Sg), Spermatids (St). $H \& E \times 1000$

Fig (2) Section of testis of Nile tilapia during spring showing: Sperms (S), Spermatogonia (Sg), Spermatocytes (Sc), Interstitial tissues (In) H\&E X40 

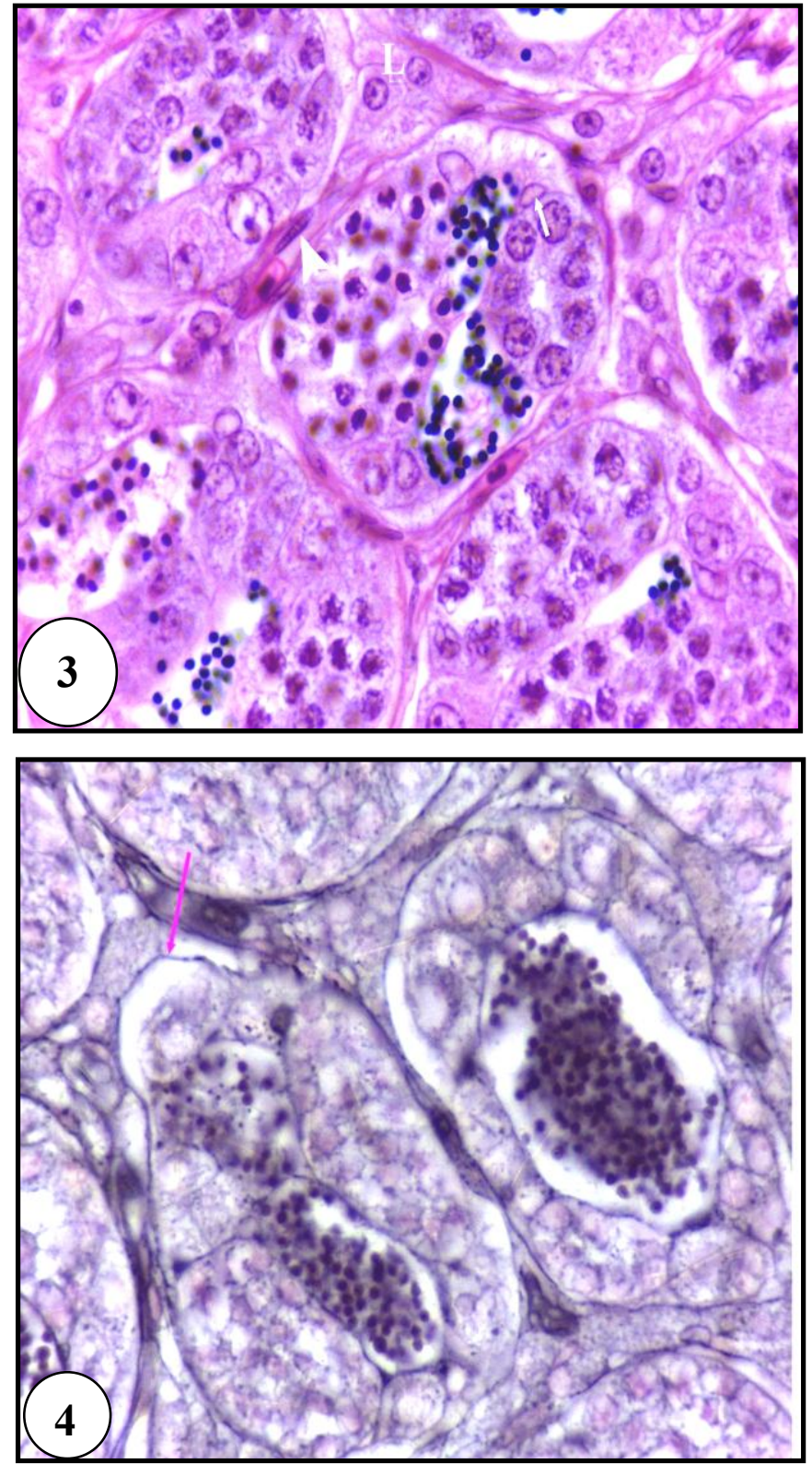

Fig (3): Section of testis of Nile tilapia during summer showing: Sertoli cells around the cyst (arrow), Myoid cell around the testicular tubules (arrow head), Leydig cells (L). $\mathrm{H} \& \mathrm{E} X 1000$

Fig (4): Section of testis of Nile tilapia during spring showing: Reticular fibers around each tubule (arrow). Gomori's reticuline stain X1000 

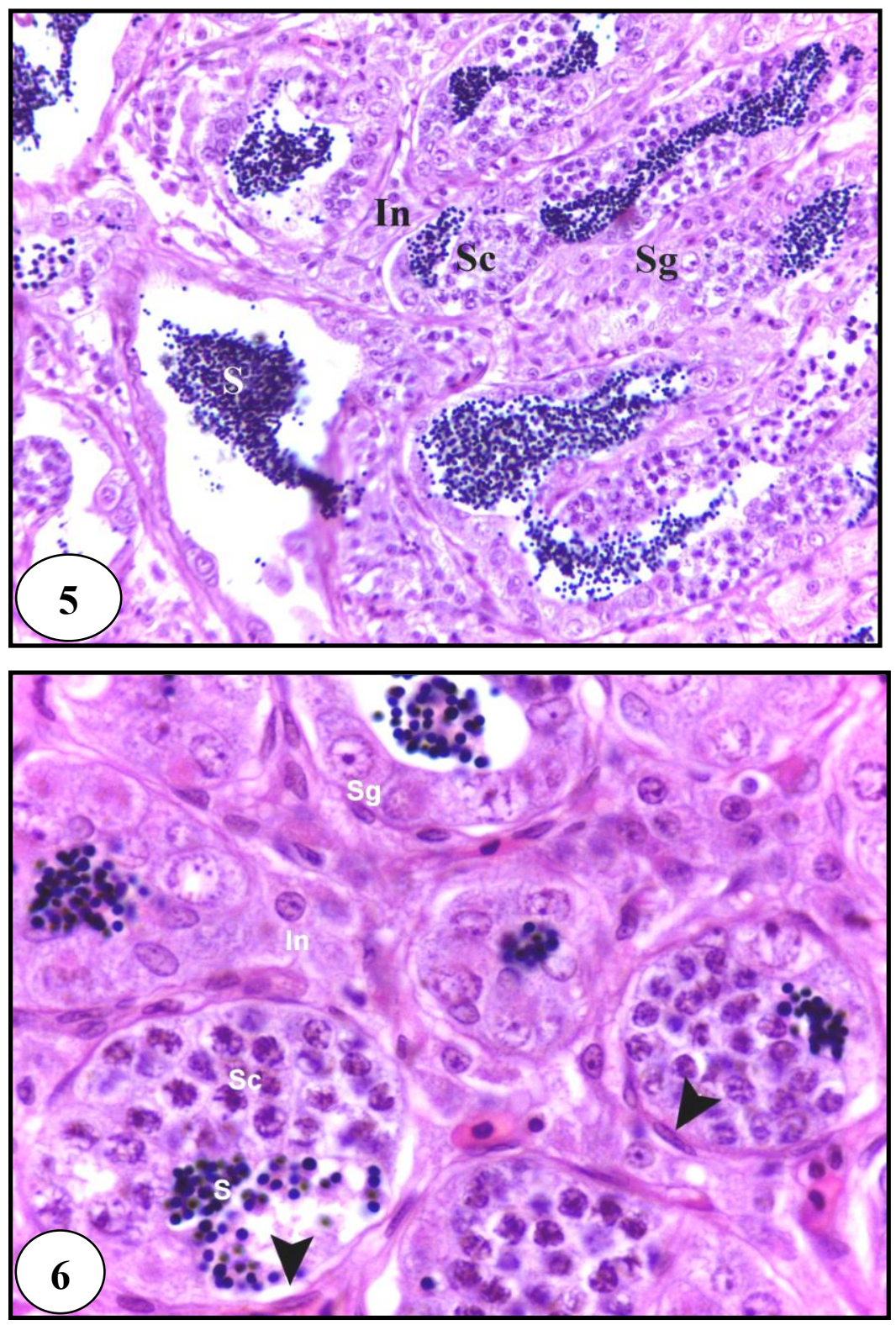

Fig (5): Section of testis of Nile tilapia during summer showing: Sperms (S), Spermatogonia (Sg), Spermatocytes (Sc), interstitial tissues (In). H\&E X400

Fig (6): Section of testis of Nile tilapia during summer showing: Spermatogonia (Sg), Spermatocytes (Sc), Interstitial tissues contain Leydig cells (In), Myoid cell around the testicular tubule (arrow head), Sperms (S). H\&E X1000 

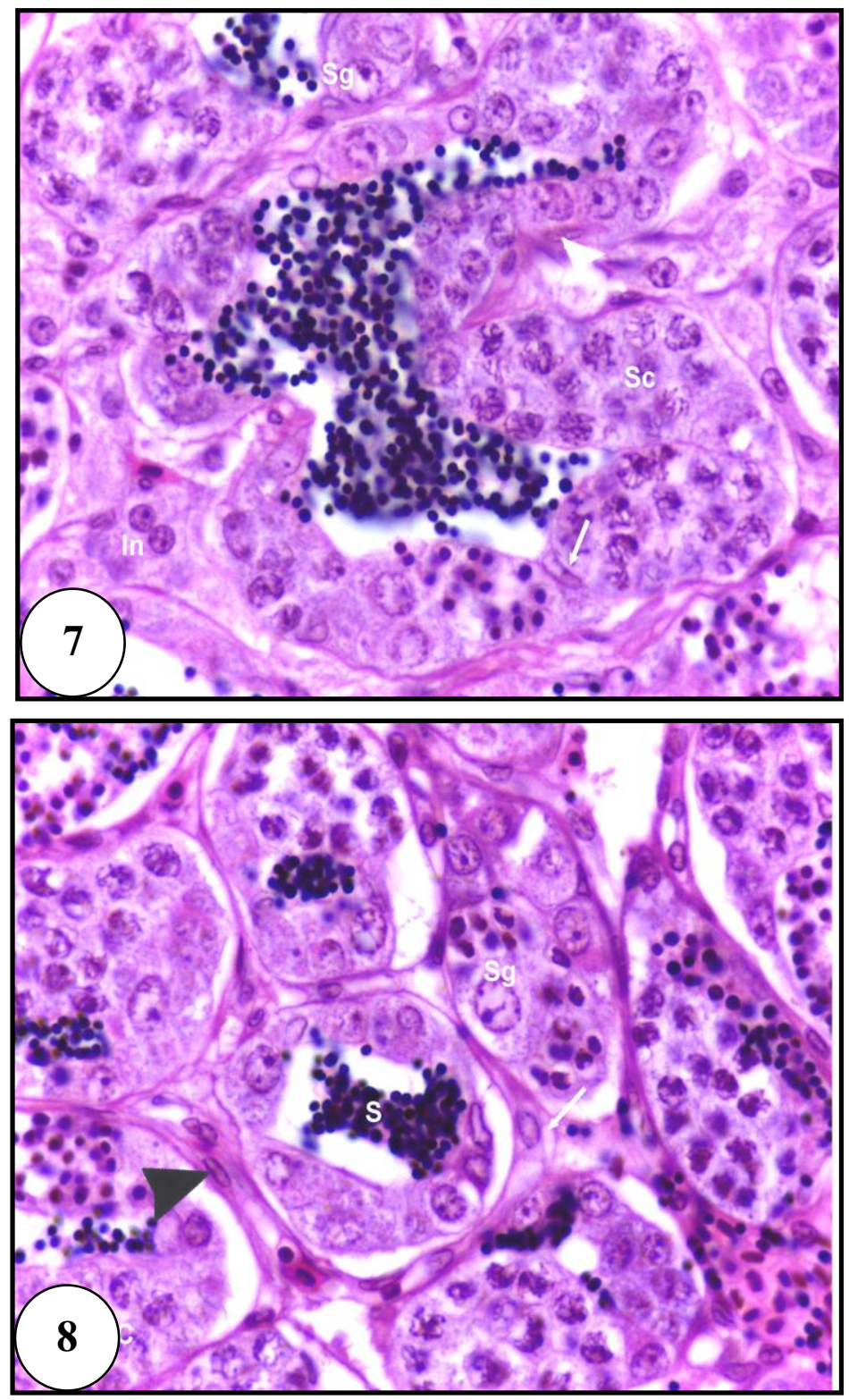

Fig (7): Section of testis of Nile tilapia during summer showing: Spermatogonia (Sg), Spermatocytes (Sc), Interstitial tissues contain Leydig cells (In), Myoid cell around the testicular tubule (arrow head), Sertoli cells around the cyst (arrow). H\&E X1000

Fig ( 8): Section of testis of Nile tilapia during autumn showing: Sperms (S), Spermatogonia (Sg), Spermatocytes (Sc), Sertoli cells at the periphery of the tubule (arrow), Myoid cell around the testicular tubule (arrow head). H\&E, X1000 

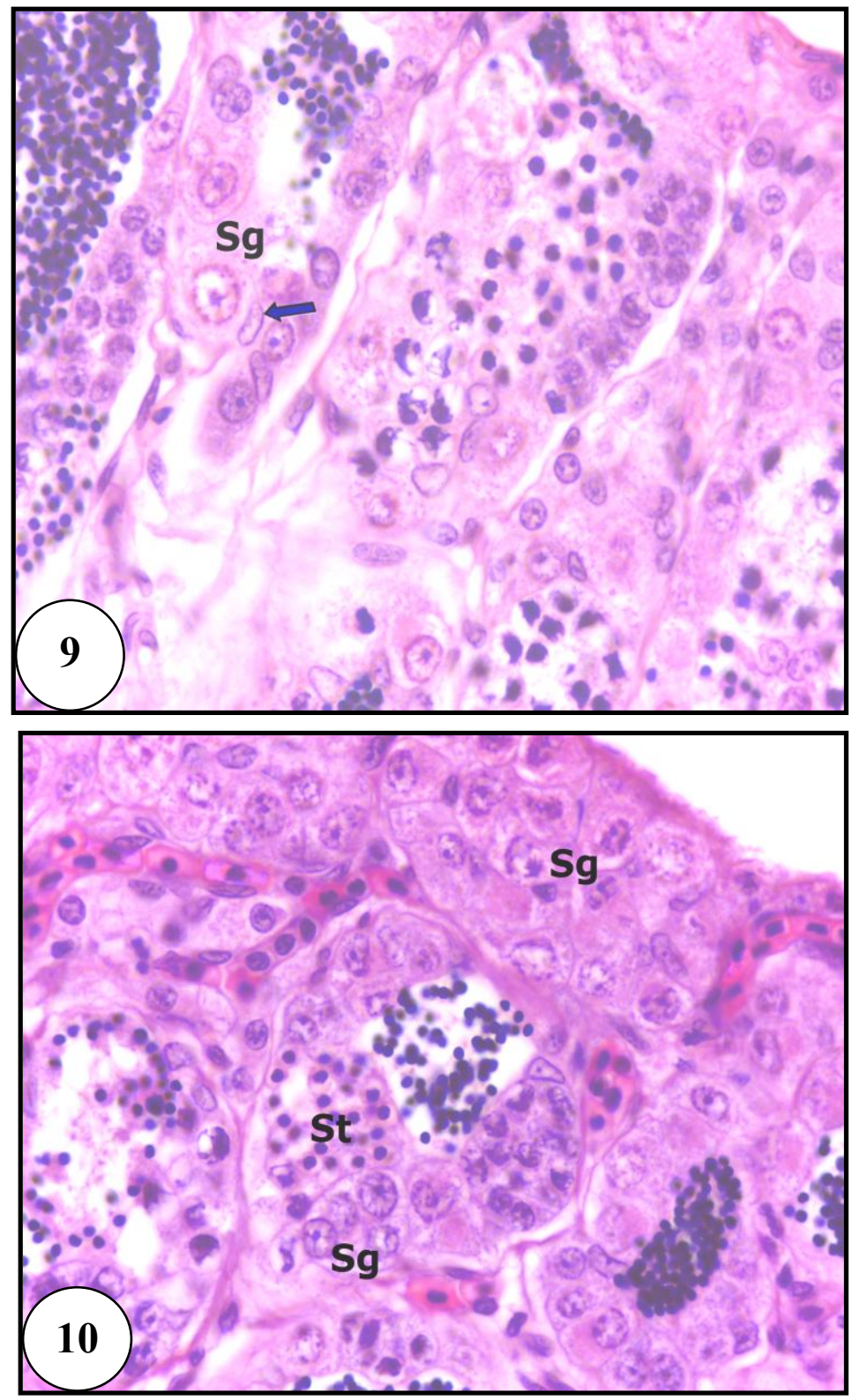

Fig (9): Section of testis of Nile tilapia during autumn showing: Spermatogonia (Sg), Sertoli cells around the Spermatogonia (type B) (arrow). H\&E X1000

Fig (10): Section of testis of Nile tilapia during autumn showing: Spermatogonia (type A under tunica albuginea and type B in cysts) (Sg), Spermatids (St). H\&E X1000 

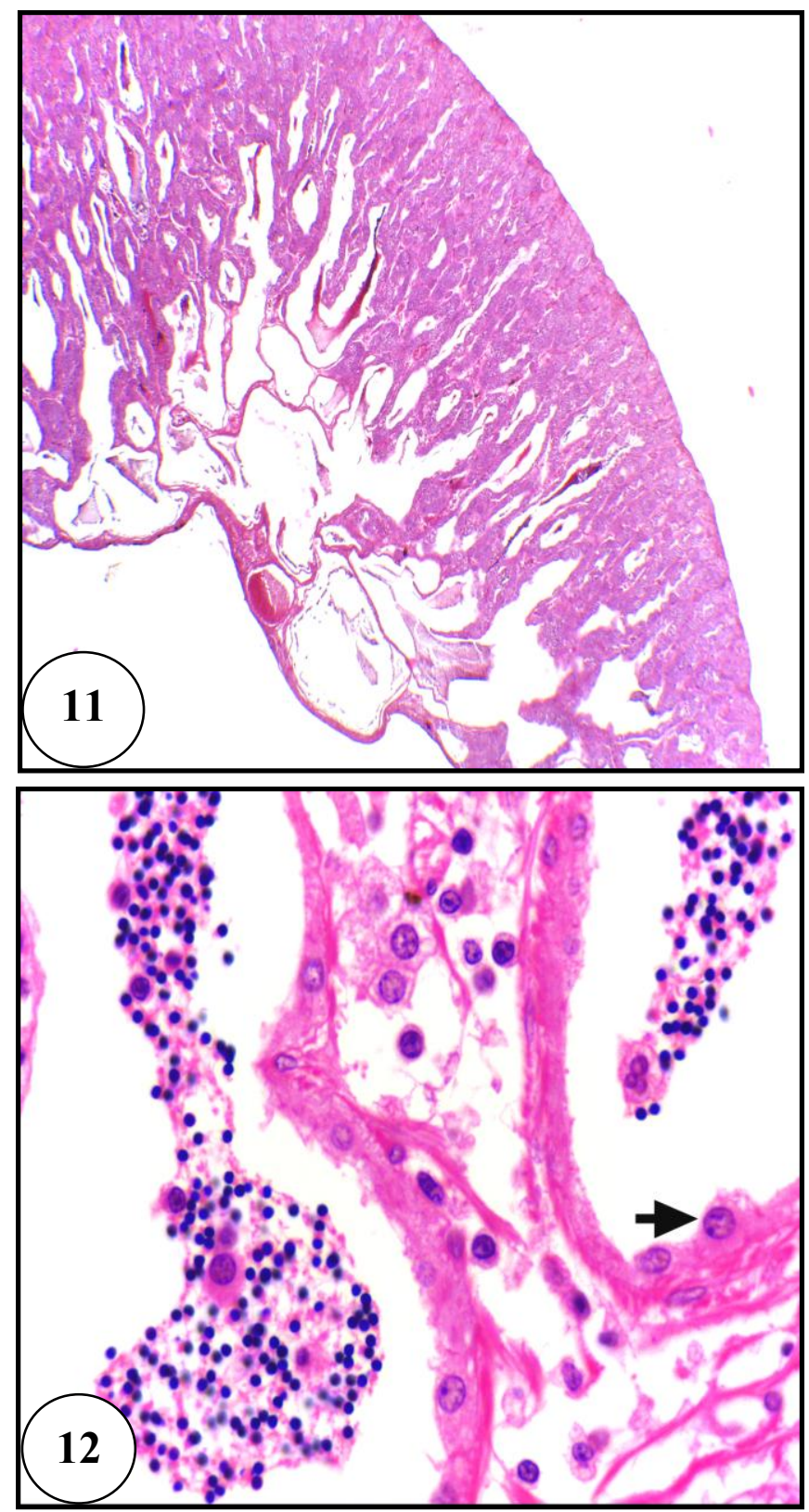

Fig (11): Section of testis of Nile tilapia during winter showing: Testis appeared evacuated from spermatozoa. H\&E X40

Fig (12): Section of testis of Nile tilapia during winter showing: Phagocytic cells (arrow). H\&E X400. 